\title{
Molecular systematics of Echinops L. (Asteraceae, Cynareae): A phylogeny based on ITS and trnL-trnF sequences with emphasis on sectional delimitation
}

\author{
Ismael Sánchez-Jiménez, ${ }^{1}$ Georgy A. Lazkov, ${ }^{2}$ Oriane Hidalgo ${ }^{3,4}$ \& Teresa Garnatje ${ }^{1,4}$ \\ 1 Institut Botànic de Barcelona (CSIC-ICUB), Passeig del Migdia, s.n, 08038 Barcelona, Catalonia, Spain \\ 2 Laboratory of Flora, Institute for Biology and Soil, Academy of Sciences, Chui Str. 265, 720071, Bishkek, Kyrgyzstan \\ 3 Plant Development and Evolution, Department of Environmental and Plant Biology, Ohio University, Porter Hall 500, Athens, Ohio \\ 45701, U.S.A. \\ 4 Both authors contributed equally to the design and supervision of this work. \\ Author for correspondence: Ismael Sánchez-Jiménez, ismasanchez83@gmail.com
}

\begin{abstract}
The monogeneric subtribe Echinopsinae of Cynareae (Asteraceae) was analysed using nrDNA ITS and plastid trnL$\operatorname{trn} F$ for 81 of the ca. 120 species, representing all Echinops sections except Cenchrolepis and Pterolepis. Maximum parsimony and Bayesian analyses were used for each dataset and for the combined data. The resulting molecular phylogenetic framework resolves Echinops as monophyletic and confirms the inclusion of E. acantholepis (=Acantholepis orientalis) within the genus. Echinops is divided into two lineages, one consisting of E. sect. Chamaechinops and sect. Acantholepis (almost exclusively annual or biennial), and the other the remaining sections (almost all perennial). Our results support an infrageneric classification of Echinops into nine previously recognized sections: Acantholepis (= Nanechinops), Chamaechinops, Echinops (= Terma), Hamolepis, Hololeuce, Oligolepis, Phaeochaete, Psectra and Ritropsis, all resolved as strongly monophyletic after some species relocations. The status of E. sect. Phaeochaete and the sectional assignment of E. onopordum, E. pungens and E. transcaucasicus remain to be clarified. The evolution of involucral bracts is congruent with the phylogenetic framework and supports the sectional classification. Annual pollen type does not constitute an autapomorphy of the clade grouping the annuals but may represent the ancestral character state for the entire genus.
\end{abstract}

Keywords Acantholepis; Bayesian inference; Compositae; Echinopsinae; morphological characters

\section{INTRODUCTION}

The genus Echinops s.l. (including Acantholepis Less.) is the only member of Echinopsinae (Cass.) Dumort., one of the five subtribes of Cynareae Lam. \& DC., otherwise known as Cardueae Cass. (Susanna \& al., 2006). It is characterized by the presence of uniflowered capitula aggregated into second order spherical or oval heads, this syncephalia being a unique feature within the tribe (Petit, 1997). Echinops comprises ca. 120 species (Bobrov, 1997; Susanna \& Garcia-Jacas, 2007) distributed in tropical Africa, the Mediterranean basin, temperate regions of Eurasia, reaching Central Asia, Mongolia and north-eastern China, with the greater number of species occurring in the Caucasus and the Middle East (for a distribution map of the genus, see Jäger, 1987).

The strong morphological uniformity of Echinops makes its taxonomical delimitation to be almost unquestioned, but it also hinders the attempts at establishing natural groups and an infrageneric classification. The most complete analysis of the genus was made by Bunge (1863) who recognized twelve sections, seven of them new. After Bunge, revisions were published by Fries (1923), Jeffrey (1968) and Tadesse (1997) for tropical Africa, Hedge (1975) for the Turkish flora, Kožuharov (1976) for the European taxa, Rechinger (1979) and Mozaffarian (2008) for the Iranian flora, and Bobrov (1997) for the former U.S.S.R. territories. Morphological characters used for infrageneric classifications of Echinops are almost limited to the bracts of the uniflowered capitula, such as their number, or the degree of connation of the inner bracts (Fig. 1; Table 1; Hedge, 1975; Kožuharov, 1976; Rechinger, 1979; Bobrov, 1997). In this genus, the diversity of the involucral bracts seems to be related to the fact that the one-seeded capitulum is the unit of dispersal, and therefore has an adaptive value (Davis, 1956). On the contrary, the pappus - a main source of key taxonomical characters for other Cynareae - plays no role in dissemination and is very short and quite uniform throughout Echinops species. Other features like the type and density of indumentum on stems, leaves and phyllaries display a certain amount of variability that provides taxonomically useful characters (Mozaffarian, 2006).

A previous attempt at molecular phylogenetic reconstruction for Echinops (Garnatje \& al., 2005) consisted of a parsimony analysis based on the ITS region and representing 30 species and the monotypic genus Acantholepis; that is, hardly a quarter of all the members in the group. Echinops (Acantholepis included) was consistently resolved as a natural group in this study, as well as in molecular phylogenies of the tribe Cynareae (Garcia-Jacas \& al., 2002; Susanna \& al., 2006). The inclusion of Acantholepis orientalis Less. within Echinops species (Garnatje $\&$ al., 2005) agreed with its treatment as E. acantholepis (Jaubert \& Spach, 1848). Nevertheless, most authors had considered 
this taxon as an independent genus close to Echinops (Hedge, 1975; Dittrich, 1977, 1996; Rechinger, 1979; Petit, 1988, 1997; Bremer, 1994; Bobrov, 1997). The molecular evidence of Garnatje \& al. (2005) suggested a tight relationship between Acantholepis and E. nanus, an assumption consistent with life cycles (they are both annual), and pollen type data (Garnatje \& Martín, 2007). Nevertheless, using traditional morphological characters, Acantholepis is well distinguished from Echinops species by having second-order head involucral bracts well-developed and patent; the outer ones are similar to the leaves and exceed notably the remaining parts of the syncephalia, whereas these bracts in Echinops are comparatively small and hidden. The karyological data also differentiate Acantholepis and Echinops, although both Acantholepis and E. gmelini present a metacentric chromosome pair notably larger than the rest, which is not found in other species (Garnatje \& al., 2004; Sánchez-Jiménez $\&$ al., 2009). However there exists the doubt that, in the previous molecular phylogenetic reconstruction, the association of the two annual taxa at the base of the tree could be produced by long-branch attraction, the parsimony method being particularly sensitive to this bias (Philippe \& al., 2005). Therefore, the relationship between Acantholepis and annual Echinops needs to be confirmed. As stated above, the taxonomical delimitation of Echinops has not been the object of many doubts and restructurations, and in fact, apart from E. acantholepis, the only other species whose position as a member of the genus has been questioned is E. strigosus, an Ibero-mauritanian biennial species. According to palynological and leaf features, this species is isolated within the genus (Petit, 1988), which led Tomšovic (1997) to suggest its segregation from Echinops to form the monotypic genus Psectra (Endl.) Tomšovic. The ITS analysis performed by Garnatje \& al. (2005) fully resolves the systematic position of this taxon as nested within Echinops, and therefore better considered as E. strigosus. Due to the limited species sampling, the previous molecular study did not allow to test the suitability of traditional infrageneric classifications.

The ITS region has been chosen for carrying out the present study because it has provided good results for Echinops
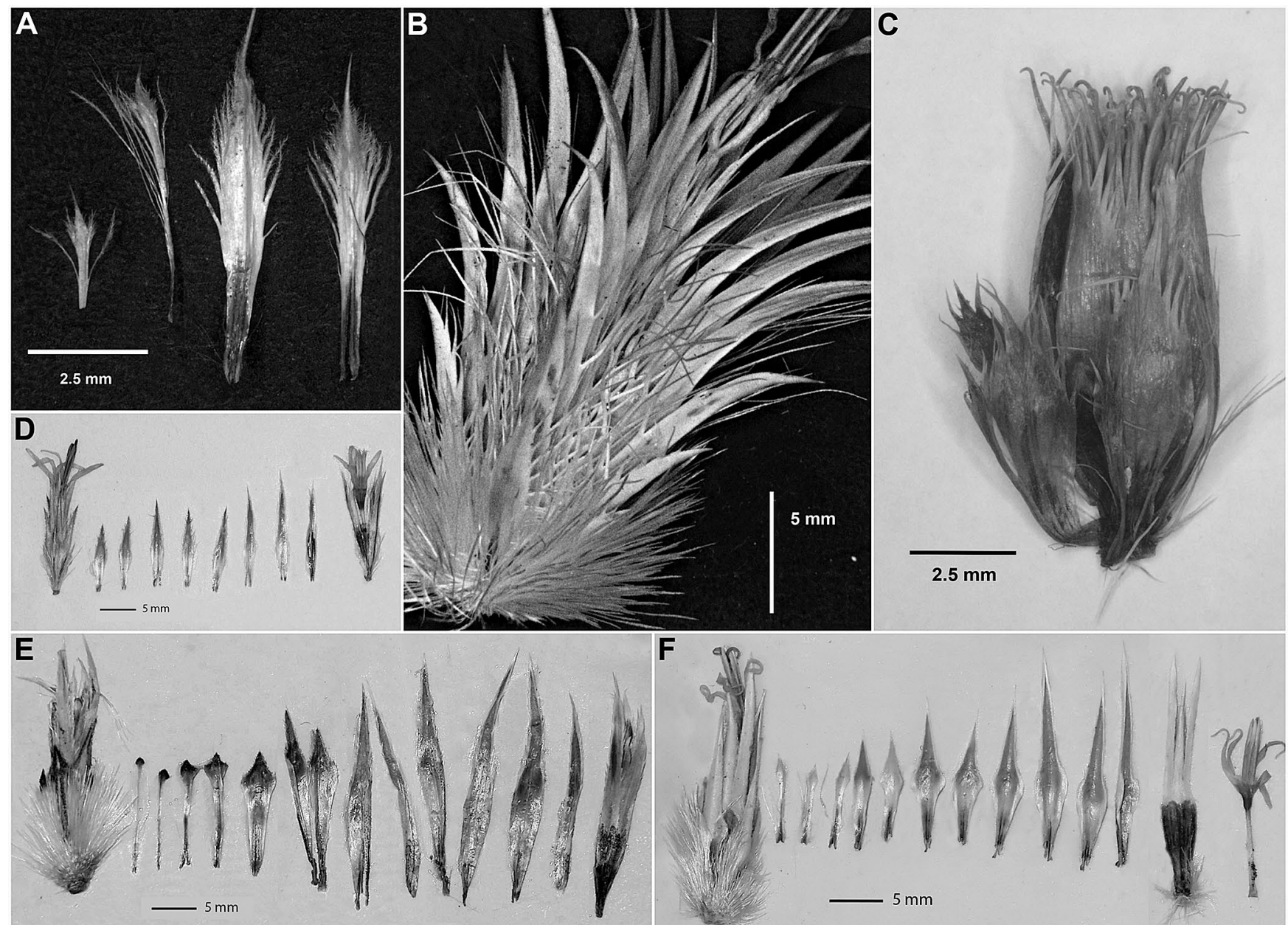

Fig. 1. Bract diversity in the genus Echinops. A, plumose bracts of E. gmelini (sect. Nanechinops); B, uniflowered capitulum of E. strigosus (sect. Psectra) with 8-9 rows of free bracts; C, hooked bracts of E. hoehnelii (sect. Hamolepis); D, dissection of E. koeltzii Rech. f. (sect. Echinops) uniflowered capitulum with the inner bracts free or slightly connate at the base; E, dissection of E. spinosissimus subsp. spinosissimus (sect. Ritropsis) uniflowered capitulum with the inner bracts united in a membranous tube; F, dissection of E. elymaiticus (sect. Oligolepis) uniflowered capitulum with the inner bracts connate forming a leather-like tube. 
(Garnatje \& al., 2005) and other genera of Cynareae (e.g., Susanna \& al., 1999; Vilatersana \& al., 2000; Wang \& al., 2005, 2007; Hidalgo \& al., 2006). The trnL-trnF region has also been used successfully in Cynareae (e.g., Wang \& Liu, 2004; Hidalgo \& al., 2006; Wang \& al., 2007) and in other groups of Asteraceae (e.g., Kiers \& al., 1999; Álvarez \& al., 2001; Bayer \& al., 2002; Liu \& al., 2006; Katinas \& al., 2008; Mort $\&$ al., 2008). The main goal of this study is to establish a comprehensive molecular phylogenetic framework of Echinops in order to (1) discuss whether or not the sections of the genus form natural groups, thus evaluating the suitability of the current classifications, and (2) link the findings to the distribution of some key morphological characters traditionally used in the infrageneric treatments of this genus.

\section{MATERIALS AND METHODS}

Plant material. - We analyzed the sequences of the internal transcribed spacers region of nrDNA (ITS1, 5.8S, ITS2) and the $\operatorname{trn} L$-trnF region of cpDNA in 89 ingroup specimens, with eight additional specimens for the ITS region and four for the trnL-trnF. Eighty-eight taxa corresponding to 81 species and 10 subspecies (three for E. ritro, two for E. sphaerocephalus, five for E. spinosissimus) were represented. We have sequenced a well-rounded representative sample of the genus, which includes the type species of all sections except for the two African sections Cenchrolepis (described as monotypic) and Pterolepis (three species assigned; Fries, 1923). The entire geographic distributional range of the genus is covered, although the tropical African area is still somewhat weakly represented in our sampling (4 of the 25 species considered by Tadesse, 1997). Four species, Brachylaena discolor, from tribe Tarchonantheae Kostel, Cardopatium corymbosum and Cousiniopsis atractyloides, from subtribe Cardopatiinae Less., and Tugarinovia mongolica, from subtribe Carlininae (Cass.) Dumort. were chosen as outgroup members according to previous works based on morphological (Petit, 1988) and molecular characters (Susanna \& al., 2006). The source of the investigated species is shown in the Appendix in the Electronic Supplement to the online version of this article. Both previously published and new sequences were used in the analysis; the present study contributes 71 new sequences for the ITS region and 89 for the $\operatorname{trnL} L-\operatorname{trnF}$ one. The species have been named according to Greuter (2006-2009).

DNA isolation, PCR amplification and sequencing. Total genomic DNA was extracted using a Nucleospin Plant II kit (Macherey-Nagel, GmbH \& Co., Düren, Germany) from sheets provided by different herbaria, silica gel-dried material collected during our expeditions, and young plants from germinated cypsela cultivated in the greenhouse of the Botanical Institute of Barcelona (see Appendix in the Electronic Supplement).

The plastid $\operatorname{trn} L-\operatorname{trn} F$ region includes the $\operatorname{trn} L$ intron, the $3^{\prime} \operatorname{trn} L$ (UAA) exon, and the intergenic spacer between $\operatorname{trn} L$ (UAA) and $\operatorname{trn} \mathrm{F}$ (GAA), which were amplified and sequenced

Table 1. Description and type species of Echinops sections according to Bunge (1863), Fries (1923), Rechinger (1979) and Bobrov (1997). Classification according to Rechinger (1979), with sections from outside the Iranian region added (Fries, 1923; Bobrov, 1997). Echinops sect. Psectra follows Bunge (1863) and Tomšovic (1997). Number of species in E. sect. Echinops, sect. Oligolepis and sect. Ritropsis are estimates.

\begin{tabular}{|c|c|c|}
\hline Section & Type & Description \\
\hline Acantholepis (Less.) Jaub. \& Spach & E. acantholepis Jaub. \& Spach & $\begin{array}{l}\text { Bracts of the common involucre large, external ones leaf-shaped, exceeding } \\
\text { and surrounding the head. Annual plants. } 1 \text { species. }\end{array}$ \\
\hline Echinops & E. sphaerocephalus L. & $\begin{array}{l}\text { Involucral bracts } 16-25 \text {, the inner free to base or slightly connate. Perennial } \\
\text { plants. About } 50 \text { species. }\end{array}$ \\
\hline Hololeuce Rech.f. & E. hololeucus Rech.f. & $\begin{array}{l}\text { Involucral bracts } 15-20 \text {, free, the outer largely plumose. Perennial plants. } 1 \\
\text { species. }\end{array}$ \\
\hline Nanechinops Bunge & E. nanus Bunge & $\begin{array}{l}\text { Involucral bracts 16-20, free, largely plumose, perennial; anther appendages } \\
\text { awn-shaped below, bearded above. Annual plants. } 3 \text { species. }\end{array}$ \\
\hline Psectra Endl. & E. strigosus L. & Involucral bracts free, in $8-9$ rows. Perennial plants. 1 species. \\
\hline Ritropsis Greuter \& Rech.f. & E. orientalis Trautv. & $\begin{array}{l}\text { Involucres of } 16-25 \text { bracts; inner united in a membranous cylindrical tube. } \\
\text { Perennial plants. About } 25 \text { species. }\end{array}$ \\
\hline Terma Endl. & E. exaltatus Schrad. & $\begin{array}{l}\text { Inner involucral bracts free; pappus cup-shaped, split only above. Perennial } \\
\text { plants. } 4 \text { species. }\end{array}$ \\
\hline
\end{tabular}


together. Universal primers trnL-c, forward, and trnL-f, reverse, and, in some cases, trnL-d, reverse, and trnL-e, forward, were used for amplifying and sequencing the $\operatorname{trn} L-\operatorname{trn} F$ region (Taberlet \& al., 1991). The polymerase chain reaction (PCR) procedure included a hot start at $95^{\circ} \mathrm{C}$ for $1 \min 35 \mathrm{~s}, 34$ cycles of 1 min denaturation at $93^{\circ} \mathrm{C}, 1 \mathrm{~min}$ annealing at $58^{\circ} \mathrm{C}, 1$ min extension at $72^{\circ} \mathrm{C}$, and a final 10 min extension at $72^{\circ} \mathrm{C}$. The ITS1 spacer, 5.8S gene and ITS2 spacer (ITS region) were amplified and sequenced together. The ITS region was amplified by PCR with the forward primer ITS1, and the reverse primer ITS4 (White \& al., 1990), as described in Soltis \& Kuzoff (1993). In some cases, we used the 1406F (Nickrent \& al., 1994) as forward primer. Sequencing primers ITS1, ITS4 and sometimes ITS2 and ITS3 (reverse and forward, respectively; White \& al., 1990) were used.

Both ITS and $\operatorname{trnL}$-trnF products were purified with a QIAquick ${ }^{\circledR}$ PCR Purification Kit (Qiagen Inc., Valencia, California, U.S.A.) or DNA Clean \& Concentrator ${ }^{\mathrm{TM}}-5$ D4004 (Zymo Research, Orange, California, U.S.A.). Direct sequencing of the amplified DNA segments was performed using the BigDye ${ }^{\circledR}$ Terminator Cycle Sequencing v.3.1 (PE Biosystems, Foster City, California, U.S.A.), following the protocol recommended by the manufacturer. Nucleotide sequencing was carried out at the Serveis Cientificotècnics of the University of Barcelona on an ABI PRISM 3700 DNA analyzer (PE Biosystems, Foster City, California, U.S.A.).

Phylogenetic analyses. - Nucleotide sequences were edited and aligned manually with SeaView v.4 (Galtier \& al., 1996) and BioEdit v.7.0.9 (Hall, 1999). ITS and trnL-trnF analyses were performed both separately and combined. Positions 38-39 and 119-121 of ITS matrix were excluded for the analyses because of their ambiguous alignment.

Bayesian analyses. - Datasets were analysed using MrModeltest v.2.3 (Nylander, 2004) to determine the sequence evolution models that best described the present data. These models were used to perform Bayesian analysis using MrBayes v.3.1.2 (Ronquist \& Huelsenbeck, 2003), which runs two parallel analyses simultaneously. Four Markov chains were run simultaneously for 106 generations, and these were sampled every 100 generations. Data from the first 1000 generations were discarded as the "burn-in" period, after confirming that likelihood values were stabilized prior to the 1000th generation. The 50\% majority rule consensus tree and posterior probability (PP) of nodes were calculated from the remaining 9001 trees sampled.

Parsimony analysis. - Heuristic analyses of the ITS and the combined data using PAUP* v.4.0b10 (Swofford, 2003) failed because of tree storage limitations. As a result, heuristic analysis was carried out with the PAUPRat approach (Nixon, 1999; Sikes \& Lewis, 2001), a tool for implementing parsimony ratchet searches using PAUP*. For parsimony ratchet analyses, uninformative characters were deactivated and $15 \%$ of the informative characters were perturbed. The analyses consisted of 10 runs of 200 iterations with tree bisection reconnection (TBR) branch swapping, one tree held at each iteration. On the other hand, parsimony analyses of $\operatorname{trn} L-\operatorname{trn} F$ region involved heuristic searches conducted with PAUP* using TBR branch swapping with character states specified as unordered and unweighted. To locate islands of most parsimonious trees (Maddison, 1991), 1000 replicates were performed with random taxon addition. All most parsimonious trees (MPTs) were saved and PAUP* was used to compute a strict consensus. Tree lengths, consistency index (CI) and retention index (RI) were calculated excluding uninformative characters.

Bootstrap (BS; Felsenstein, 1985) was carried out to obtain support estimates of the nodes of the trees selected. A fast stepwise-addition bootstrap analysis was performed in PAUP* using 2,000,000 replicates with the default options because of the size of the dataset. The fast stepwise-addition bootstrap method usually provides underestimates as compared to those obtained with branch swapping bootstrap analyses (Mort \& al., 2000).

\section{RESULTS}

Bayesian analyses. - In some cases Akaike information criterion (AIC) and hierarchical Likelihood Ratio Tests (hLRT) implemented in MrModeltest v.2.3 (Nylander, 2004) determined different models as best fitting the datasets (Table 2). When this occurred, we performed analyses with all models. No inconsistencies were detected between the resulting trees, this leading us to show only the results obtained with the AIC model (Fig. 2), because this approach presents several important advantages over the hLRTs for model selection (Posada \& Buckley, 2004).

Parsimony analyses. - The numerical results of the combined ITS and $\operatorname{trnL}$-trnF dataset, as well as for separated regions, are given in Table 2.

Congruence of the trees. - Bayesian analyses produced trees with better resolution than parsimony; however they do not show topological discordance for significantly supported

Table 2. Statistics of the PAUP* and Bayesian analyses. Consistency and homoplasy indexes are calculated excluding uninformative characters.

\begin{tabular}{|c|c|c|c|c|}
\hline \multicolumn{2}{|l|}{ Dataset } & Combined $^{\mathrm{a}}$ & ITS $^{\mathrm{a}}$ & $\operatorname{trn} L-\operatorname{trn} F$ \\
\hline \multicolumn{2}{|l|}{ Ingroup taxa } & 89 & 97 & 93 \\
\hline \multicolumn{2}{|c|}{ Total characters } & 1519 & 659 & 860 \\
\hline \multicolumn{2}{|c|}{ Informative substitutions } & 240 & 216 & 25 \\
\hline \multicolumn{2}{|c|}{ Number of MPTs } & 1954 & 1983 & 32 \\
\hline \multicolumn{2}{|c|}{ Number of steps } & 681 & 652 & 33 \\
\hline \multicolumn{2}{|c|}{ Consistency index (CI) } & 0.5051 & 0.4923 & 0.8182 \\
\hline \multicolumn{2}{|c|}{ Retention index (RI) } & 0.7643 & 0.7690 & 0.9455 \\
\hline \multicolumn{2}{|c|}{ Rescaled consistency index (RC) } & 0.3861 & 0.3786 & 0.7736 \\
\hline \multirow{5}{*}{ 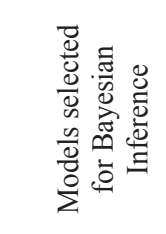 } & $\mathrm{AIC}$ & $\mathrm{GTR}+\mathrm{I}+\mathrm{G}$ & $\mathrm{GTR}+\mathrm{I}+\mathrm{G}$ & $\mathrm{GTR}+\mathrm{G}$ \\
\hline & hLRT & $\mathrm{GTR}+\mathrm{I}+\mathrm{G}$ & $\mathrm{GTR}+\mathrm{G}$ & $\mathrm{F} 81+\mathrm{G}$ \\
\hline & hLRT2 & $\mathrm{GTR}+\mathrm{I}+\mathrm{G}$ & $\mathrm{SYM}+\mathrm{G}$ & $\mathrm{F} 81+\mathrm{I}$ \\
\hline & hLRT3 & $\mathrm{GTR}+\mathrm{I}+\mathrm{G}$ & $\mathrm{SYM}+\mathrm{I}+\mathrm{G}$ & $\mathrm{F} 81+\mathrm{G}$ \\
\hline & hLRT4 & $\mathrm{GTR}+\mathrm{I}+\mathrm{G}$ & $\mathrm{SYM}+\mathrm{G}$ & $\mathrm{F} 81+\mathrm{I}$ \\
\hline
\end{tabular}

${ }^{a}$ PAUPRat approach (Nixon, 1999; Sikes \& Lewis, 2001) performed. 


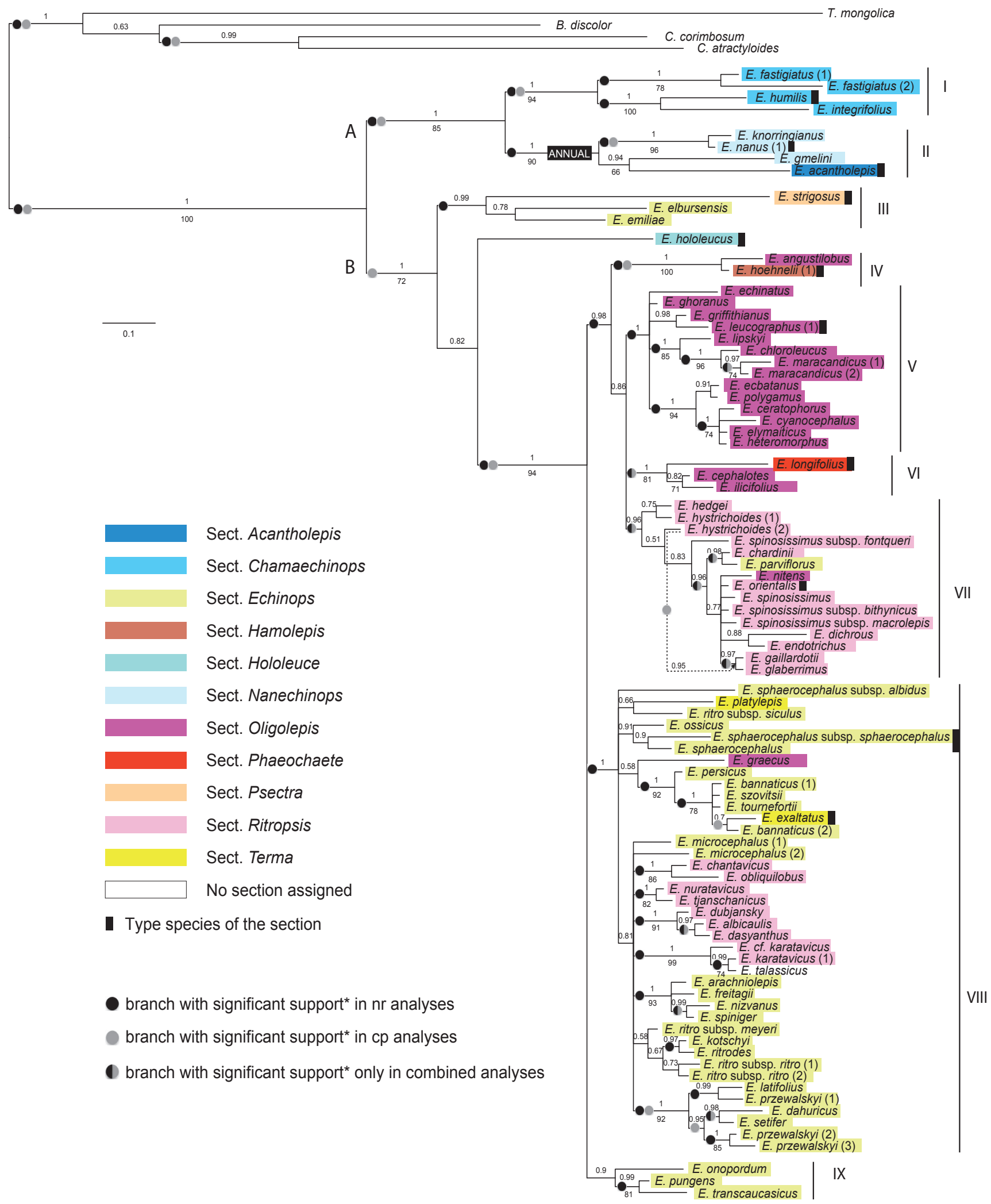

Fig. 2. Majority rule consensus tree resulting from Bayesian analysis of the combined ITS + trnL-trnF dataset; numbers above branches are Bayesian posterior probabilities and below branches Bootstrap ( $\geq 70 \%)$. * indicates PP $\geq 0.95$ and/or BS $\geq 80 \%$. Sections are those considered by various authors before this study. Numbers in parentheses after species names differentiate individuals of the same species; A and B denote the two main lineages; roman numerals on the tree indicate the sections as treated in this work. Discontinuous line indicates the incongruence between combined and $\operatorname{trn} L-\operatorname{trn} F$ trees (see text for explanation). 


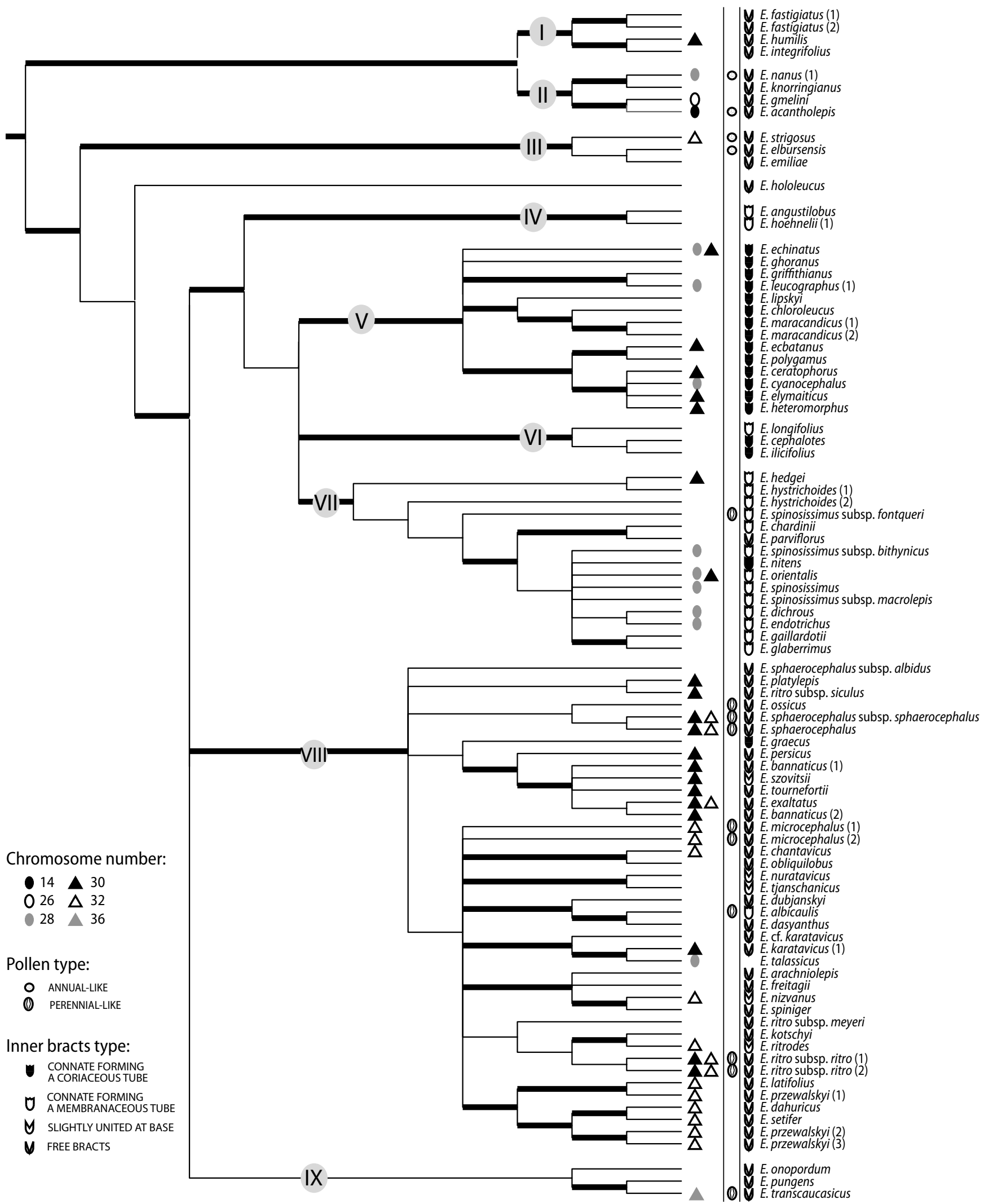

Fig. 3. Distribution of selected morphological characters in the phylogeny. See text for bract morphology, Garnatje \& Martín (2007) for pollen and Sánchez-Jiménez \& al. (2009) and references therein for chromosome numbers. Numbers in parentheses after species names differentiate individuals of the same species; roman numerals on the tree indicate the sections as treated in this work. Thick lines are branches with PP $\geq 0.95$. 
branches. This led us to present only the tree obtained with the Bayesian analysis of the combined dataset (Fig. 2). Posterior probabilities and bootstrap values are indicated on this tree. Moreover, inspection of topologies and branch support values do not show any conflict between the plastid and nuclear DNA phylogenetic reconstructions. The only inconsistency is between the combined and plastid trees, and concerns the position of $E$. hystrichoides (specimen 2). This specimen groups with E. gaillardotii and E. glaberrimus in trnL-trnF analyses ( $\mathrm{PP}=$ 0.95 ), while its position in combined analyses is not compatible with such an association. The great compatibility of the nuclear and chloroplastic datasets is also expressed in terms of branch supports, as $20 \%$ of supported branches occur only in combined analyses. Notwithstanding, the branch grouping E. bannaticus (specimen 2) and E. exaltatus in trnL-trnF analyses $(\mathrm{PP}=0.98)$ lost significance in combined analyses $(\mathrm{PP}=0.70)$, this indicating a certain level of incongruence, even quite localized.

Morphological characters. - The diversity of inner involucral bracts of the uniflowered capitula within Echinops is distributed into four main categories (Fig. 3): free bracts (FB); bracts slightly united at the base (SUB); connate, forming a membranous tube (CMT); and connate, forming a coriaceous tube (CCT).

\section{DISCUSSION}

\section{Phylogenetic and taxonomic implications}

The new phylogenetic framework established by these analyses shows Echinops to be monophyletic ( $\mathrm{PP}=1.00, \mathrm{BS}=$ $100 \%$; Fig. 2), and confirms previous results pointing towards the inclusion of E. acantholepis (= Acantholepis orientalis) within the genus (Garnatje \& al., 2005). Echinops is divided into two main lineages, one comprising the representatives of E. sect. Chamaechinops, sect. Nanechinops and E. acantholepis (lineage A, PP $=1.00, \mathrm{BS}=85 \%$; Fig. 2), the other including the remaining Echinops species (lineage $\mathrm{B}, \mathrm{PP}=1.00$, BS $=72 \%$; Fig. 2). The tree provides a valuable resolution at the sectional level, permitting the comparison of the molecular phylogenetic framework with the traditional classifications of the genus. Our results resolved the infrageneric classification of Echinops in nine sections, and highlighted the need to do some species relocations to make these sections monophyletic:

Echinops sect. Chamaechinops. - (Clade I, PP $=1.00$, BS $=94 \%$; Fig. 2) This includes plants restricted to the Tian Shan and Sayan mountains, in northeast Central Asia, which are characterized by pappus bristles that are awn-shaped and remotely serrate above and not bearded (Table 1; Bobrov, 1997).

Echinops sect. Acantholepis. - (Clade II, PP = 1.00, BS $=90 \%$; Fig. 2) All the species from E. sect. Nanechinops are represented in the analysis and form a monophyletic group along with $E$. acantholepis. This clade is well characterized by involucral bracts with a plumose margin (Fig. 1A; Table 1). Clade II includes the types of two different sections, namely E. sect. Acantholepis (E. acantholepis) and sect. Nanechinops (E. nanus), which were described simultaneously (Bunge,
1863), even although Bunge assigned E. sect. Acantholepis to Spach because that author had previously described Echinops subg. Acantholepis (Jaubert \& Spach, 1848). In such a case of equal priority, either $E$. sect. Acantholepis or sect. Nanechinops can be chosen for the combined section, and we must make a decision (Art. 11.5 of the $I C B N$; McNeill \& al., 2006): we select here Echinops sect. Acantholepis and place Echinops sect. Nanechinops in synonymy under $E$. sect. Acantholepis.

The close relationship between E. sect. Acantholepis and sect. Chamaechinops has been suggested on the basis of the likely biennial habit of $E$. integrifolius (Kamelin \& Tscherneva, 1971). Bunge (1863) also described both E. humilis and E. integrifolius as biennial plants. Moreover, Mulkidzhanyan (Bobrov, 1997) stated that "genus Acantholepis is a derivative from the genus Echinops and seems to have originated from an ancestor of the type E. integrifolius and E. humilis". Our results support these assumptions of close affinities between the two sections (lineage $\mathrm{A}, \mathrm{PP}=1.00, \mathrm{BS}=85 \%$; Fig. 2).

Echinops sect. Psectra. - (Clade III, PP = 0.99; Fig. 2) Our phylogenetic trees are not consistent with the segregation of E. strigosus in Psectra strigosa (L.) Tomšovic (Tomšovic, 1997). The phylogenetic position of this taxon is clearly within Echinops in an early-branched lineage (clade III, Fig. 2), as stated in previous work (Garnatje \& al., 2005). The relationship between E. emiliae and E. strigosus is confirmed with significant statistical support, and E. elbursensis is added to this group of species.

This group shows an interesting, strongly disjunct distribution. Both E. elbursensis and E. emiliae are narrow endemics from the Central Alborz mountain range (Iran) and the Antalya mountains (Turkey), respectively (Hedge, 1975; Rechinger, 1979), whereas E. strigosus grows below an altitude of $500 \mathrm{~m}$. and is distributed in the north of Africa and the southern parts of the Iberian Peninsula (Valdés, 2002). The so called "Kiermack" disjunctions, between the eastern and western Mediterranean, or even Central Asia and the western Mediterranean (Ribera \& Blasco-Zumeta, 1998), have been reported for a number of taxa (Braun-Blanquet \& Bolòs, 1957; Davis \& Hedge, 1971; Thorne, 1972; Willis, 1996; Oberprieler, 2005; Meerow \& al., 2006; Pérez-Collazos \& al., 2009). Processes of dispersal and vicariance occurring during the Miocene (15-10 Ma) between the eastern and western Mediterranean are documented for the Asteraceae, in the tribe Anthemideae (Oberprieler, 2005).

Echinops sect. Hololeuce. - (Fig. 2) Echinops hololeucus was described as constituting the monotypic E. sect. Hololeuce, and related to $E$. sect. Nanechinops (in the present classification, E. sect. Acantholepis) on the basis of its plumose bracts (Rechinger, 1979). Echinops hololeucus appears as isolated within lineage B (Fig. 2), and therefore its affinities should be searched more likely amongst this lineage than with sect. Acantholepis, which belongs to lineage A (Fig. 2).

Echinops sect. Hamolepis. $-($ Clade IV, $\mathrm{PP}=1.00, \mathrm{BS}=$ $100 \%$; Fig. 2) The African species E. angustilobus and E. hoehnelii were classified by Fries (1923) in E. sect. Oligolepis and sect. Hamolepis respectively. The two species are sister in the molecular phylogeny, and consequently the transfer of $E$. 
angustilobus to sect. Hamolepis is required in order to keep the sections monophyletic. Echinops angustilobus was the only representative of $E$. sect. Oligolepis having CMT inner involucral bracts, and its new sectional assignment results in two homogeneous sections for bract type (Fig. 3).

Echinops sect. Oligolepis. - (Clade V; $\mathrm{PP}=1.00$; Fig. 2) This section, characterized by the presence of CCT inner involucral bracts (Rechinger, 1979; Bobrov, 1997; Fig. 1F; Table 1), is well defined in our phylogenetic analysis. Echinops cornigerus and E. kandaharensis, included only in the ITS analyses, are also located within this clade (data not shown). Echinops sect. Oligolepis is practically restricted to the Middle East. In fact, 38 of the 40 species described by Rechinger (1979) for this section in the Iranian flora are endemic.

Echinops sect. Phaeochaete. - (Clade VI, PP $=1.00, \mathrm{BS}=$ 81\%; Fig. 2) Although morphological features of E. cephalotes and E. ilicifolius are clearly attributable to E. sect. Oligolepis, these species group with E. longifolius, the type of the name of E. sect. Phaeochaete. However, this clade VI forms a polytomy with sects. Hamolepis, Oligolepis and Ritropsis, and therefore its merging with E. sect. Oligolepis, thus reconciling the molecular and morphological evidences, cannot be discarded.

Echinops sect. Ritropsis. - (Clade VII, PP $=0.96$; Fig. 2) Echinops parviflorus and E. nitens, whose morphological characters are perfectly attributable to the sections to which they were previously assigned (E. sects. Echinops and Oligolepis, respectively; Fig. 2), are now nested in E. sect. Ritropsis. This clade includes E. spinosissimus, a polymorphic taxon that has been subject to different taxonomical interpretations (Rechinger, 1943; Feinbrun, 1977; Greuter, 2003). It is mainly distributed in North Africa and the east of the Mediterranean basin, coexisting with several related taxa, like $E$. gaillardotii and E. glaberrimus (Rechinger, 1943; Feinbrun, 1977), which are also close phylogenetic relatives ( $\mathrm{PP}=0.96$; Fig. 2). Echinops tenuisectus (only on ITS analyses, data not shown) is also included in this E. spinosissimus clade. Echinops spinosissimus subsp. fontqueri, an endemism from the Rif in Morocco (Valdés, 2002) does not group with its presumed conspecifics, which supports its consideration as an independent species, namely $E$. fontqueri $\mathrm{Pau}$. We found the only case of incongruence between combined and plastid analyses for the second specimen of E. hystrichoides (see Results; Fig. 2), a species that has been related to E. spinosissimus (Tan, 1995). This finding affecting a group with such a taxonomical complexity, which probably results from a recent radiation, may be a product of hybridization.

Echinops sect. Echinops. - (Clade VIII, PP = 1.00; Fig. 2). Clade VIII comprises both types of the names of $E$. sect. Echinops and E. sect. Terma. Echinops sect. Terma is represented in our study by E. exaltatus (the type species) and E. platylepis. The two species are both nested within E. sect. Echinops representatives and do not group together. Our results agree with Kožuharov (1976) for considering E. sect. Terma a synonym of E. sect. Echinops. Echinops sect. Echinops is characterized by uniflowered capitula with 16-25 involucral bracts, the inner ones free or slightly connate at the base (Fig. 1D; Table 1; Rechinger, 1979). Bunge (1863) and Bobrov (1997) considered an additional section, E. sect. Ritro Endl., characterized by external involucral bracts deprived of glandular hairs and leather-like, whereas E. sect. Echinops s.str. species have usually glandular external involucral bracts relatively thin. Moreover, species of section Echinops s.str. grow in forest edges and shrubby thickets, whereas those of sect. Ritro are found in open habitats in steppes and semi-deserts (Bobrov, 1997). The resolution of clade VIII prevents any conclusion as to the suitability of such a classification.

Clade VIII includes a series of eight species previously assigned to E. sect. Ritropsis (Fig. 2): E. albicaulis, E. chantavicus, E. dasyanthus, E. dubjanskyi, E. karatavicus, E. obliquilobus, E. nuratavicus and E. tjanschanicus. These species were also classified in E. sect. Rytrodes Bunge (Li, 1987; Bobrov, 1997). Bunge (1863) defined $E$. sect. Rytrodes because of the connation of the inner involucral bracts in a membranous tube, a trait never observed in the type of the name of this section, E. ritrodes. This led Rechinger (1979) to transfer this species in E. sect. Echinops, and to describe a new section, E. sect. Ritropsis, whose type, E. orientalis, is characterized by CMT involucral bracts (Table 1). Our results give support to this consideration of $E$. sect. Rytrodes as a synonym of $E$. sect. Echinops. Furthermore, the phylogenetic tree also suggests that other species from $E$. sect. Rytrodes should be placed in E. sect. Echinops rather than in E. sect. Ritropsis. Morphological evidence reveals that $E$. chantavicus, E. dasyanthus, E. dubjanskyi, E. karatavicus and E. obliquilobus have FB (Bobrov, 1997), E. nuratavicus and E. tjanschanicus SUB (Li, 1987; Bobrov, 1997); and only E. albicaulis has CMT (Bobrov, 1997; Fig. 3). Therefore, E. sect. Rytrodes, as considered by Bunge (1863) and Bobrov (1997), includes several species that do not present the morphological characters used for defining it. Further, none of them have other frequent characteristics of E. sect. Ritropsis, like cornigerous capitula with middle bracts ending in long spines and leaves with large and strong spines. On the contrary, all those characters strongly resemble a general aspect similar to species from section Echinops. To sum up, the morphological evidence supports the placement of these species in E. sect. Echinops. Echinops talassicus, which has until now never been assigned to any section, is included in this group and therefore in E. sect. Echinops.

Clade IX. - ( $\mathrm{PP}=0.90 ;$ Fig. 2$)$ This clade constitutes one of the few uncertainties of our phylogenetic reconstruction regarding the assignment of species throughout Echinops sections. In fact, this is a double uncertainty, because the monophyly of the group in itself is not significantly established, and because there is a trichotomy between clades (IV, V, VI, VII), VIII and IX. If the polytomy is resolved by the grouping of E. pungens, E. onopordum and E. transcaucasicus with clade VIII, these species would remain in E. sect. Echinops, as previously stated by morphological data (Hedge, 1975), but if it is resolved in another possible topology, this would mean that these species should probably constitute a new section within the genus. Echinops polyacanthus (included only in ITS analyses) groups with $E$. pungens and E. transcaucasicus $(\mathrm{PP}=0.98$ and $\mathrm{BS}=$ $81 \%$, data not shown), a result consistent with morphological data (Hedge, 1975). 
Our results do not resolve the systematic position of Echinops onopordum, an endemic species from southwest Turkey. Nevertheless, they do permit the discarding of a possible relationship of this taxon with the E. pannosus group (represented in our phylogeny by E. emiliae) suggested by Davis (1956). Its consideration as an isolated species (Hedge, 1975) is still possible.

\section{Evolution of morphological characters}

Involucral bracts of the uniflowered capitula. - These have been consistently used for sectional characterization, especially regarding their degree of connation (Table 1). The Echinops ancestral bract type seems to be that of inner free bracts (FB), present in lineage A, and successively in the grades giving rise to $E$. sect. Psectra and sect. Hololeuce at the base of B lineage (Fig. 3). Inner involucral bracts of increasing connection degrees are found later in the tree: bracts slightly united at the base (SUB); connate, forming a membranous tube (CMT); and connate, forming a coriaceous tube (CCT; Fig. 3). Although bract types in themselves do not provide autapomorphies at a sectional level, their distribution throughout Echinops sections is quite homogeneous. Each section has only one bract type or at least one clearly dominating type (Fig. 3): FB for $E$. sects. Acantholepis, Chamaechinops, Echinops and Psectra, CMT for E. sects. Hamolepis and Ritropsis, CCT for E. sect. Oligolepis. The SUB type is exclusively found in E. sect. Echinops (Fig. 3). The association of sects. Hamolepis, Oligolepis, Phaeochaete and Ritropsis ( $\mathrm{PP}=0.98$, Fig. 2) is supported morphologically; they are characterized by connate inner involucral bracts (of CMT or CCT types) with the only exception of $E$. parviflorus (Rechinger, 1979; Tadesse, 1997).

Some sectional re-locations are quite difficult to explain on morphological bases. This is the case of E. graecus, a species with CCT inner bracts previously classified in $E$. sect. Oligolepis (Hedge, 1974; Kožuharov, 1976), which appears in our phylogenetic reconstruction nested in E. sect. Echinops (Fig. 2). The observation of uniflowered capitula of $E$. graecus at different maturation stages revealed that involucral bracts can be free at floration. We believe that connation of the inner bracts in this and other species may occur during cypsela formation. We agree with Kožuharov (1975) that connation of the bracts should be treated with caution as a differential character, in spite of the fact that it can be consistently found in several groups like E. sect. Oligolepis and sect. Ritropsis. Nevertheless, since the one-seeded capitulum is the dispersion unit in Echinops (Davis, 1956) it is not surprising that evolutionary convergence occurs for this character.

Pollen types. - Garnatje \& Martín (2007) suggested a close relationship of E. acantholepis with other annual Echinops species on the basis of pollen type. Both E. acantholepis and $E$. nanus have subprolate microechinate pollen without prominent intercolpia (annual-like pollen type), whereas a subprolate microechinate/echinate verrucoid pollen with very prominent intercolpia in the shape of a bridge is present in all the perennial species of Echinops examined at this time (perennial-like pollen; Garnatje \& Martín, 2007). Recent pollen morphological work revealed the occurrence of the annual-like pollen type in E. elbursensis (I. Sánchez-Jiménez, unpub., Fig. 3), also seen before in E. strigosus (Garnatje \& Martín, 2007), both from E. sect. Psectra (clade III, Fig. 2). Annual pollen type, which seemed at first to be restricted to species with an annual habit (Garnatje \& Martín, 2007), is in fact present in E. acantholepis, E. elbursensis, E. nanus and E. strigosus, and consequently extended to E. sect. Psectra in the B lineage (Figs. 2-3). Therefore, annual pollen type can no longer be considered as constituting an autapomorphy of the clade grouping the annuals, but it may represent the ancestral character state for the whole genus.

\section{口 CONCLUDING REMARKS}

The present study contributes to the establishment of an infrageneric classification of the genus Echinops. The sections Acantholepis, Hamolepis and Psectra were considered before as monotypic, whereas the present phylogenetic study shows they are composed of two or more species. Based on our study, only E. sect. Hololeuce remains as monotypic. More work including analysis of other molecular markers is necessary to clarify the phylogenetic relationships of species with doubtful placement. Moreover, sampling should be enlarged to include some more species belonging to the African sections. Although biogeography was not a principal aim of this work, some interesting geographical patterns were detected such as the disjunction within E. sect. Psectra and the distributions of E. sects. Chamaechinops and Oligolepis. Detailed phylogeographical analysis of sections such as $E$. sect. Ritropsis might contribute to elucidate the relationships between the floras of the Mediterranean and the Middle East. The complex taxonomy of the E. spinosissimus group could be clarified by means of population studies. A detailed study of pollen morphology and evolution in the genus Echinops might also be promising.

\section{ACKNOWLEDGEMENTS}

The authors wish to thank all the collectors, botanical gardens and herbaria cited for supplying material. Acknowledgements are given to the SYNTHESYS Project (http://www.synthesys.info/), financed by the European Community Research Infrastructure Action under the FP6 "Structuring the European Research Area" Programme, Dr. Ernst Vitek from the Naturhistorisches Museum Wien, in making possible the study of herbarium vouchers, Dr. Daniel Petit for advice and material, and Samuel Pyke and the editor-in-chief of Taxon for improvement of the English manuscript. We are also grateful to three anonymous reviewers for critically reading the manuscript. O.H. benefited of a MICINN postdoctoral contract, I.S.-J. benefited of a FPU grant and T.G. of a Marina Bueno grant, from the Ministerio de Ciencia e Innovación, Ministerio de Educación of the Spanish government and the CSIC, respectively. This work was supported by projects CGL2007-64839-C02-01/BOS of the Spanish government and 2005/ SGR/00344 of the Generalitat de Catalunya. 


\section{口 LITERATURE CITED}

Álvarez, I., Fuertes, J., Panero, J.L. \& Nieto, G. 2001. A phylogenetic analysis of Doronicum (Asteraceae, Senecioneae) based on morphological, nuclear ribosomal (ITS), and chloroplast (trnL-F) evidence. Molec. Phylog. Evol. 20: 41-64.

Bayer, R.J., Greber, D.G. \& Bagnall, N.H. 2002. Phylogeny of Australian Gnaphalieae (Asteraceae) based on chloroplast and nuclear sequences, the $\operatorname{trn} L$ intron, $\operatorname{trn} L$-trnF intergenic spacer, $m a t K$, and ETS. Syst. Bot. 27: 801-814.

Bobrov, E.G. 1997. Echinops L. Pp. 1-70 in: Shishkin, B.K. \& Bobrov, E.G. (eds.), Flora of the USSR, vol. 27. Dehra Dun: Bishen Singh, Mahendra Pal Singh; Koenigstein: Koeltz Scientific Books.

Braun-Blanquet, J. \& Bolòs, O. de. 1957. Les groupements végétaux du bassin moyen de l'Ebre et leur dynamisme. Anales Estac. Exp. Aula Dei 5: 1-266.

Bremer, K. 1994. Asteraceae: Cladistics \& classification. Portland: Timber Press.

Bunge, A. 1863. Über die Gattung Echinops. Bull. Acad. Imp. Sci. Saint-Pétersbourg 6: 390-412.

Davis, P.H. 1956. Fourteen new species from Turkey. Notes Roy. Bot. Gard. Edinburgh 22: 65-84.

Davis, P.H. \& Hedge, I.C. 1971. Floristic links between NW Africa and SW Asia. Ann. Naturhist. Mus. Wien 75: 43-57.

Dittrich, M. 1977. Cynareae - Systematic review. Pp. 999-1015 in: Heywood, V.H., Harborne, J.B. \& Turner, B.L. (eds.), The biology and chemistry of the Compositae, vol. 2. London: Academic Press.

Dittrich, M. 1996. Die Bedeutung morphologischer und anatomischer Achänen-Merkmale für die Systematik der Tribus Echinopeae Cass. und Carlineae Cass. Boissiera 51: 9-102.

Feinbrun, N. 1977. The genus Echinops in Palestine. Notes Roy. Bot. Gard. Edinburgh 35: 235-245.

Felsenstein, J. 1985. Confidence limits on phylogenies: An approach using the bootstrap. Evolution 39: 783-791.

Fries, R.E. 1923. Zur Kenntnis der ostafrikanischen Echinops-Arten. Acta Horti Berg. 8: 39-44.

Galtier, N., Gouy, M. \& Gautier, C. 1996. SeaView and Phylo_win, two graphic tools for sequence alignment and molecular phylogeny. Comput. Appl. Biosci. 12: 543-548.

Garcia-Jacas, N., Garnatje, T., Susanna, A. \& Vilatersana, R. 2002. Tribal and subtribal delimitation and phylogeny of the Cardueae (Asteraceae): A combined nuclear and chloroplast DNA analysis. Molec. Phylog. Evol. 22: 51-64.

Garnatje, T., Vilatersana, R., Susanna, A., Vallès, J. \& SiljakYakovlev, S. 2004. Contribution to the karyological knowledge of Echinops L. (Asteraceae, Cardueae) and related genera. Bot. J. Linn. Soc. 145: 337-344.

Garnatje, T. \& Martín, J. 2007. Pollen studies in the genus Echinops L. and Xeranthemum group (Asteraceae). Bot. J. Linn. Soc. 154: $549-557$.

Garnatje, T., Susanna, A., Garcia-Jacas, N., Vilatersana, R. \& Vallès, J. 2005. A first approach to the molecular phylogeny of the genus Echinops L. (Asteraceae): Sectional delimitation and relationships with the genus Acantholepis Less. Folia Geobot. 40: 407-419.

Greuter, W. 2003. The Euro + Med treatment of Cardueae (Compositae)-generic concepts and required new names. Willdenowia 33: 49-61.

Greuter, W. 2006-2009. Compositae (pro parte majore). In: Greuter, W. \& Raab-Straube, E. von (eds.): Compositae. Euro+Med Plantbase-the information resource for Euro-Mediterranean plant diversity. Retrieved 1 Aug. 2009 from http://ww2.bgbm.org/ EuroPlusMed/.

Hall, T.A. 1999. BioEdit: A user-friendly biological sequence alignment editor and analysis program for Windows 95/98/NT. Nucleic Acids Symp. Ser. 41: 95-98.

Hedge, I.C. 1974. Echinops. Pp. 237-239 in: Davis, P.H. (ed.), Materials for a Flora of Turkey XXX: Compositae, I. Notes Roy. Bot. Gard. Edinburgh 33: 207-264.

Hedge, I.C. 1975. Echinops L. Pp. 609-622 in: Davis, P.H. (ed.), Flora of Turkey and the East Aegean Islands, vol. 5. Edinburgh: Edinburgh Univ. Press.

Hidalgo, O., Garcia-Jacas, N., Garnatje, T. \& Susanna, A. 2006. Phylogeny of Rhaponticum (Asteraceae, Cardueae-Centaureinae) and related genera inferred from nuclear and chloroplast DNA sequence data: Taxonomic and biogeographic implications. Ann. Bot. 97: 705-714.

Jäger, E.J. 1987. Arealkarten der Asteraceen-Tribus als Grundlage der ökogeographischen Sippencharakteristik. Bot. Jahrb. Syst. 108: 481-497.

Jaubert, H.-F. \& Spach, E. 1847-1850. Illustrationes plantarum orientalum, vol. 3. Paris: apud Roret bibliopolam.

Jeffrey, C. 1968. Notes on Compositae (III): The Cynareae in East Tropical Africa. Kew Bull. 22: 107-140.

Kamelin, R.V. \& Tscherneva, O.V. 1971. A new species of the genus Echinops L. from the section Chamaechinops Bunge. Novosti Sist. Vyssh. Rast. 8: 262-265.

Katinas, L., Crisci, J.V., Schmidt-Javaily, R., Williams, C., Walker, J., Drew, B., Bonifacino, J.M. \& Sytsma, K.J. 2008. Evolution of secondary heads in Nassauviinae (Asteraceae, Mutisieae). Amer. J. Bot. 95: 229-240.

Kiers, A.M., Mes, T.H.M., Van der Meijden, R. \& Bachmann, K. 1999. Morphologically defined Cichorium (Asteraceae) species reflect lineages based on chloroplast and nuclear (ITS) DNA data. Syst. Bot. 24: 645-659.

Kožuharov, S.I. 1975. Notes on some European species of Echinops L. and Jurinea Cass. Pp: 41-43 in: Heywood, V.H. (ed.), Flora Europaea - Notulae Systematicae ad Floram Europaeam spectantes. Bot. J. Linn. Soc. 71: 39-50.

Kožuharov, S.I. 1976. Echinops L. Pp: 212-214 in: Tutin, T.G., Heywood, V.H., Burges, N.A., Moore, D.M., Valentine, D.H., Walters, S.M. \& Webb, D.A. (eds.), Flora europaea, vol. 4. Cambridge: Cambridge Univ. Press.

Li, A. 1987. Species nova generis Echinops L. (Asteraceae) e PamiroAlaj. Novosti Sist. Vyssh. Rast. 24: 201-202.

Liu, J.-Q., Wang, Y.-J., Wang, A.-L., Hideaki, O. \& Abbott, R.J. 2006. Radiation and diversification within the Ligularia-Cremathodium-Parasenecio complex (Asteraceae) triggered uplift of the Qinghai-Tibetan Plateau. Molec. Phylog. Evol. 38: 31-49.

Maddison, D.R. 1991. The discovery and importance of multiple islands of most-parsimonious trees. Syst. Zool. 40: 315-328.

McNeill, J., Barrie, F.R., Burdet, H.M., Demoulin, V., Hawksworth, D.L., Marhold, K., Nicolson, D.H., Prado, J., Silva, P.C., Skog, J.E., Wiersema, J.H. \& Turland, N.J. (eds.) 2006. International code of botanical nomenclature (Vienna Code): Adopted by the Seventeenth International Botanical Congress Vienna, Austria, July 2005. Regnum Vegetabile 146. Rugell, Liechtenstein: Gantner.

Meerow, A.W., Francisco-Ortega, J., Kuhn, D.N. \& Schnell, R.J. 2006. Phylogenetic relationships and biogeography within the Eurasian clade of Amaryllidaceae based on plastid $n d h F$ and nrDNA ITS sequences: Lineage sorting in a reticulate area? Syst. Bot. 31: 42-60.

Mort, E.M., Randle, C.P., Kimball, R.T., Tadesse, M. \& Crawford, D.J. 2008. Phylogeny of Coreopsideae (Asteraceae) inferred from nuclear and plastid DNA sequences. Taxon 57: 109-120.

Mort, E.M., Soltis, P.S., Soltis, D.E. \& Mabry, M.L. 2000. Comparison of three methods for estimating internal support on phylogenetic trees. Syst. Biol. 49: 160-161.

Mozaffarian, V. 2006. A taxonomic survey of Echinops L. tribe Echinopeae (Asteraceae) in Iran: 14 new species and diagnostic keys Iranian J. Bot. 11: 197-239.

Mozaffarian, V. 2008. Compositae: Anthemideae and Echinopeae. In: Assadi, M., Maassoumi, A.A. \& Mozaffarian, V. (eds.), Flora of Iran, no. 59. Teheran: Research Institute of Forests and Rangelands.

Nickrent, D.L., Schuette, K.P. \& Starr, E.M. 1994. A molecular 
phylogeny of Arceuthobium (Viscaceae) based on nuclear ribosomal DNA internal transcribed spacer sequences. Amer. J. Bot. 81: 1149-1160.

Nixon, K.C. 1999. The parsimony ratchet, a new method for rapid parsimony analysis. Cladistics 15: 407-414.

Nylander, J.A.A. 2004. MrModeltest, version 2. Program distributed by the author. Evolutionary Biology Centre, Uppsala University.

Oberprieler, C. 2005. Temporal and spatial diversification of CircumMediterranean Compositae-Anthemideae. Taxon 54: 951-966.

Pérez-Collazos, E., Sánchez-Gómez, P., Jiménez, F. \& Catalán, P. 2009. The phylogeographical history of the Iberian steppe plant Ferula loscosii (Apiacee): A test of the abundant-centre hipótesis. Molec. Ecol. 18: 848-861.

Petit, D.P. 1988. Le genre Echinops L. (Compositae: Cardueae). 1. Position phylétique et interprétation de l'incapitulescence. Candollea 43: 467-481.

Petit, D.P. 1997. Generic interrelationships of the Cardueae (Compositae): A cladistic analysis of morphological data. Pl. Syst. Evol. 207: 173-203.

Philippe, H., Zhou, Y., Brinkmann, H., Rodrigue, N. \& Delsuc, F. 2005. Heterotachy and long-branch attraction in phylogenetics. BMC Evol. Biol. 5: 50. doi:10.1186/1471-2148-5-50.

Posada, D. \& Buckley, T.R. 2004. Model selection and model averaging in phylogenetics: Advantages of Akaike information criterion and Bayesian approaches over likelihood ratio tests. Syst. Biol. 53: 793-808.

Rechinger, K.H. 1943. Flora Aegaea: Flora der Inseln und Halbinseln des Ägäischen Meeres. Vienna: Springer.

Rechinger, K.H. (ed.). 1979. Flora des Iranischen Hochlandes und der umrahmenden Gebirge. Compositae III - Cynareae. Graz: Akademische Druck und Verlagsanstalt.

Ribera, I. \& Blasco-Zumeta, J. 1998. Biogeographical links between steppe insects in the Monegros region (Aragon, NE Spain), the Eastern Mediterranean, and Central Asia. J. Biogeogr. 25: 969986.

Ronquist, F. \& Huelsenbeck, J.P. 2003. MrBayes 3: Bayesian phylogenetic inference under mixed models. Bioinformatics 19: 1572-1574.

Sánchez-Jiménez, I., Pellicer, J., Hidalgo, O., Garcia, S., Garnatje, T. \& Vallès, J. 2009. Chromosome numbers in three Asteraceae tribes from Inner Mongolia (China), with genome size data for Cardueae. Folia Geobot. 44: 307-322.

Sikes, D.S. \& Lewis, P.O. 2001. PAUPRat: PAUP* implementation of the parsimony ratchet, beta software, version 1 . Distributed by the authors, Department of Ecology and Evolutionary Biology, University of Connecticut, Storrs, U.S.A.

Soltis, D.E. \& Kuzoff, R.K. 1993. ITS sequence homogeneity within and among populations of Lomatium grayi and L. laevigatum (Umbelliferae). Molec. Phylog. Evol. 2: 166-170.

Susanna, A. \& Garcia-Jacas, N. 2007. The tribe Cardueae. Pp. 135-158 in: Kadereit, J.W. \& Jeffrey, C. (eds.), The families and genera of vascular plants, vol. 8, Flowering plants; Eudicots; Asterales. Heidelberg: Springer.

Susanna, A., Garcia-Jacas, N., Hidalgo, O., Vilatersana, R. \& Garnatje, T. 2006. The Cardueae (Compositae) revisited: Insights from ITS, trnL-trnF, and matK nuclear and chloroplast DNA analysis. Ann. Missouri Bot. Gard. 93: 150-171.

Susanna, A., Garnatje, T. \& Garcia-Jacas, N. 1999. Molecular phylogeny of Cheirolophus (Asteraceae: Cardueae-Centaureinae) based on ITS sequences of nuclear ribosomal DNA. Pl. Syst. Evol. 214: $147-160$.

Swofford, D.L. 2003. PAUP*: Phylogenetic analysis using parsimony (*and other methods), version 4. Sunderland, Massachusetts: Sinauer.

Taberlet, P., Gielly, L., Pautou, G. \& Bouvet, J. 1991. Universal primers for amplification of three non-coding regions of chloroplast DNA. Pl. Molec. Biol. 17: 1105-1109.

Tadesse, M. 1997. A revision of the genus Echinops (CompositaeCardueae) in tropical Africa. Kew Bull. 52: 879-901.

Tan, K. 1995. Seven new species of Echinops (Asteraceae). Ann. Bot. Fenn. 32: 117-126.

Thorne, R.F. 1972. Major disjunctions in the geographic ranges of seed plants. Quart. Rev. Biol. 47: 365-411.

Tomšovic, P. 1997. Some palynological observations on the genus Echinops (Asteraceae) and their taxonomic implications. Preslia 69: 31-33.

Valdés, B. 2002. Echinops L. Pp: 723-724 in: Valdés, B., Rejdali, M., Achhal el Kadmiri, A., Jury, L.L. \& Montserrat, J.M. (eds.), Checklist of vascular plants of $N$ Morocco with identification keys, vol. 2. Madrid: CSIC.

Vilatersana, R., Susanna, A., Garcia-Jacas, N. \& Garnatje, T. 2000 Generic delimitation and phylogeny of the Carduncellus-Carthamus complex (Asteraceae) based on ITS sequences. Pl. Syst. Evol. 221: 89-105.

Wang, Y.J. \& Liu, J.Q. 2004. Phylogenetic analyses of Saussurea sect. Pseudoeriocoryne (Asteraceae: Cardueae) based on chloroplast DNA trnL-F sequences. Biochem. Syst. Ecol. 32: 1009-1023.

Wang, Y.J., Liu, J.Q. \& Miehe, G. 2007. Phylogenetic origins of the Himalayan endemic Dolomiaea, Diplazoptilon and Xanthopappus (Asteraceae: Cardueae) based on three DNA regions. Ann. Bot. 99: 311-322.

Wang, Y.J., Pan, J.T., Liu, S.W. \& Liu, J.Q. 2005. A new species of Saussurea (Asteraceae) from Tibet and its systematic position based on ITS sequence analysis. Bot. J. Linn. Soc. 147: 349-356.

White, T.J., Bruns, T., Lee, S. \& Taylor, J. 1990. Amplification and direct sequencing of fungal ribosomal RNA genes for phylogenetics. Pp. 315-322 in: Innis, M., Gelfand, D., Sninsky, J. \& White, T. (eds.), PCR protocols: A guide to methods and applications. San Diego: Academic Press.

Willis, K.J. 1996. Where did all the flowers go? The fate of temperate European flora during glacial periods. Endeavour 20: 110-114. 